\title{
Community prevalence of methicillin and vancomycin resistant Staphylococcus aureus in and around Bangalore, southern India
}

\author{
Prevalência de Staphylococcus aureus resistente à meticilina e à vancomicina em comunidade \\ no entorno de Bangalore, Índia do Sul
}

\section{Rajendra Goud ${ }^{1,2}$, Soham Gupta ${ }^{3}$, Ujjwal Neogi ${ }^{2,3}$, Deepali Agarwal ${ }^{4}$, Kesava Naidu ${ }^{1}$, Raju Chalannavar and Gaddad Subhaschandra ${ }^{1}$}

\begin{abstract}
Introduction: Staphylococcus aureus is a known colonizer in humans and has been implicated in community acquired soft tissue infections. However emergence of methicillin resistant $S$. aureus (MRSA) has aroused great concern worldwide. This study aimed to determine the prevalence of MRSA in the community of Bangalore, southern India. Methods: Swabs were collected from anterior nares, forearm, dorsum and palm of the hands of 1,000 healthy individuals residing in and around Bangalore, belonging to different socioeconomic strata and age groups. Results: Analysis verified that $22.5 \%$ and $16.6 \%$ of the individuals presented Staphylococcus aureus and MRSA, respectively, at any of the three sites. Vancomycin resistance was observed in $1.4 \%$ of the $S$. aureus isolates, which was confirmed by detection of the vanA gene. It was interesting to note that $58.8 \%$ of the children in the age group 1-5 years-old presented MRSA, the highest percentage compared to other age groups of $<1(44.4 \%)$ year-old, $5-20(21.7 \%)$ years-old, $>40$ (11\%) years-old and 20-40 (9.9\%) years-old. Among the population of various socioeconomic strata, maximum MRSA colonization was observed among doctors $(22.2 \%)$, followed by upper economic class (18.8\%), lower economic class (17.7\%), apparently healthy hospital in-patients (16.5\%), nurses (16\%) and middle economic class (12.5\%). Most of the MRSA isolates were capsular polysaccharide antigen type 8 (57.1\%). Conclusions: There is a need for continuous surveillance and monitoring of the presence of MRSA in the community and a clearer understanding of the dynamics of the spread of MRSA will assist in controlling its dissemination. Keywords: Staphylococcus aureus. Methicillin resistance. Vancomycin resistance. Healthy population. Colonization.
\end{abstract}

\section{RESUMO}

Introdução: O Staphylococcus aureus é conhecido por ser um colonizador em humanos sendo implicado em infecções comunitárias dos tecidos moles. Contudo, a resistência à meticilina e emergência de $S$. aureus meticilina resistentes (MRSA) têm despertado preocupação em todo o mundo. O presente estudo visa encontrar a prevalência de MRSA na comunidade de Bangalore, sul da India. Métodos: Suabes foram coletados de narinas anteriores, antebraço e dorso da palma de 1.000 indivíduos saudáveis, residentes em Bangalore e nas proximidades, pertencentes a diferentes estratos socioeconômicos e faixas etárias. Resultados: Observouse que $22,5 \%$ e $16,6 \%$ dos indivíduos foram abrigar Staphylococcus aureus e MRSA, respectivamente, em qualquer um dos três locais. Dos $S$. aureus isolados, 1,4\% também foram resistentes à vancomicina, o que foi confirmado pela detecção do gene vanA. Foi interessante notar que 58,8\% das crianças na faixa etária de 1-5 anos foram abrigar MRSA, o mais elevado em comparação com outros grupos etários de < $1(44,4 \%)$ ano, 50-20 (21,7\%) anos, > 40 (11\%) anos e 20-40 (9,9\%) anos. Entre a população de diferentes estratos socioeconômicos, a colonização de MRSA máxima foi observada entre os médicos $(22,2 \%)$, seguida pela classe econômica superior $(18,8 \%)$, classe baixa $(17,7 \%)$, pacientes aparentemente saudáveis $(16,5 \%)$ enfermeiros (16\%) e classe econômica média (12,5\%). A maioria dos MRSA isolados eram do tipo polissacarídeo capsular antígeno $8(57,1 \%)$. Conclusões: Há uma necessidade de vigilância e monitorização contínua da presença de MRSA na comunidade, bem como uma melhor compreensão da dinâmica de propagação de MRSA pode ajudar no controle da disseminação. Palavras-chaves: Staphylococcus aureus. Resistência à meticilina. Resistência à vancomicina. População saudável. Colonização.

1. Departamento de Estudos em Microbiologia, Universidade Gulbarga, Gulbarga, Karnataka, India. 2. Departamento de Microbiologia, Faculdade de Gestão Administrativa, Bangalore, India. 3. Departamento de Microbiologia, Faculdade de Medicina St. John's, Bangalore, India. 4. Curso de Odontologia, Faculdade Seema, Ghaziabad, India. 5. Departamento de Biotecnologia e Tecnologia de Alimentos, Universidade de Tecnologia, Durban, Africa do Sul.

Address to: Dr. Rajendra Goud. Dept ${ }^{\circ}$ Microbiologia/Faculdade de Gestão Administrativa. 560083 Bangalore, India.

Phone: $91802782-8657$

e-mail: goud.rn@gmail.com

Received in 05/10/2010

Accepted in 19/01/2011

\section{INTRODUCTION}

Staphylococcus aureus is ubiquitous in nature and a known colonizer in humans. Community acquired soft tissue infections due to $S$. aureus is quite common $^{1}$. Recently, community acquired $S$. aureus has raised concerns due to increasing methicillin resistance. Methicillin resistant Staphylococcus aureus (MRSA) infections do not respond to beta-lactam antibiotics and vancomycin is the drug of choice ${ }^{2-4}$. MRSA has been implicated in both community acquired and hospital acquired infections and many of the clinical infections arise from the spread from healthy carriers. The anterior nares are the most common site for colonization, due to moist squamous epithelium and ventilation, and are also responsible for dissemination in the community. Even healthy individuals carrying MRSA present a small risk of contracting an invasive infection.

Thus, it is imperative to determine the prevalence of MRSA as colonizers in the community, as well as presence of vancomycin resistance among them.

\section{METHODS}

In between april 2003 to december 2007, 1000 individuals ( $\mathrm{M}: \mathrm{F}=3: 2)$ of various Socio-economic status based on the monthly per capita income (MPCI) in Rs. namely upper economic class (MPCI $>$ Rs. 20000) ( $\mathrm{n}=324)$, middle economic class (MPCI Rs. 5,000-20,000) ( $\mathrm{n}=233)$, lower economic class (MPCI<Rs. 5,000) $(\mathrm{n}=181)$, doctors $(\mathrm{n}=27)$, nurses ( $\mathrm{n}=144)$, apparently healthy hospital in-patients $(\mathrm{n}=91)$, belonging to the age groups $(<1$ year-old $[\mathrm{n}=9], 1-5$ years-old $[\mathrm{n}=24], 5-20$ years-old $[\mathrm{n}=434] ; 20-40$ years-old $[\mathrm{n}=424]$ and $>40$ yearsold $[n=109])$, who were not on any antibiotic therapy and residing in the City of Bangalore and the adjacent Kolar district were recruited. Following free informed consent, swabs were collected from the anterior nares for resident flora and from the forearm, dorsum and palm of the hands for transient flora from 1,000 individuals. Transport swabs (Himedia, India) were used for sample collection and transportation to the 
laboratory. Culture and identification was performed, according to standard procedures ${ }^{5}$. All the $S$. aureus isolates were screened for methicillin and vancomycin resistance using the modified Kirby Bauer disc diffusion method, according to the NCCLS guidelines ${ }^{6}$. All the vancomycin resistant strains were further confirmed by detecting the van $A$ gene by polymerase chain reaction using the primers UNRG-Fp-5'- CATGAATAGAATAAAAGTTGCAATA-3' and UNRG- Rp- 5' CCCCTTTAACGCTAATACGATCAA described earlier by Tiwari et $\mathrm{al}^{7}$.

For all the strains of $S$. aureus that were isolated, including MRSAs, capsular antigen typing was performed against specific antisera of type- 5 and 8 capsular serotype strains, as previously described by Paul et $\mathrm{al}^{8}$.

\section{Ethical considerations}

The Ethical Review Board of Gulbarga University approved the study. Sampling was performed after obtaining oral consent from the subjects.

\section{RESULTS}

From the three anatomical sites of the 1,000 individuals screened, 1,023 coagulase negative Staphylococci (CoNS) and 282 S. aureus were isolated, of which 205 were MRSA. Among the CoNS, 58.8\% were isolated from the anterior nares $(\mathrm{n}=588), 26.2 \%$ from the forearm $(n=262)$ and $17.3 \%$ were from the dorsum and palm of the hands $(\mathrm{n}=173)$. For $S$. aureus, $22.5 \%$ were isolated from the anterior nares $(n=225), 2.4 \%$ from the forearm $(n=24)$ and $3.3 \%$ from the dorsum and palm of the hands $(\mathrm{n}=33)$. The distribution of MRSA was highest in the anterior nares $(16.6 \% ; n=166)$, followed by the forearm $(2 \% ; \mathrm{n}=20)$ and the dorsum and palm of the hands $(1.9 \% ; n=9)$. All the patients presenting S. aureus as transient flora on their forearms and the dorsum and palm of the hands also presented S. aureus in their anterior nares and thus the individual prevalence of $S$. aureus determined was $22.5 \%$. A similar value was determined for MRSA, with an individual MRSA prevalence of $16.6 \%$.

The distribution of $S$. aureus and MRSA according to age is presented in Table 1. The greatest presence of MRSA was observed in the age group 1-5 (58.3\%) years-old, followed by < 1 (44.4\%) yearold, 5-20 (21.7\%) years-old, > 40 (11\%) years-old and 20-40 (9.9\%) years-old. Although a high percentage of MRSA was determined for resident flora in the age groups $<1$ year-old and 1-5 years-old, the percentage of MRSA as transient flora was very low.

The prevalence of $S$. aureus and MRSA according to occupation and socioeconomic status is presented in the Table 2. Of some interest was the fact that $22.2 \%$ of the doctors presented MRSA as resident flora and $3.7 \%$ as transient flora, the highest values for any group. Doctors were followed by individuals from the higher economic class (18.8\%), the lower economic class (17.7\%), apparently healthy in-patients $(16.5 \%)$ and nurses $(16 \%)$, while the lowest values occurred in the middle economic class (12.5\%).

Vancomycin resistance was observed in the $1.4 \%(n=4)$ of the S. aureus isolates. Vancomycin resistance was confirmed by PCR amplification of the vanA gene. All the vancomycin resistant strains were resistant to methicillin, except one.

The presence of type 5 and type 8 capsular antigen types among the S. aureus and MRSA isolates is shown in Table 3. Capsular antigen type 8 was the most common among both S. aureus (54.3\%) and MRSA isolates (57.1\%) compared to type 5, which showed a presence of $21.6 \%$ of S. aureus and $21 \%$ of MRSA. Among non-type 5/non-type 8 isolates, $24.1 \%$ were $S$. aureus and $21.9 \%$ were MRSA.

\begin{tabular}{|c|c|c|c|c|c|c|c|c|}
\hline \multirow{2}{*}{$\begin{array}{l}\text { Age groups } \\
\text { (years) }\end{array}$} & \multirow{2}{*}{$\begin{array}{c}\text { Staphylococcal } \\
\text { isolates }\end{array}$} & \multicolumn{2}{|c|}{$\begin{array}{c}\text { Anterior } \\
\text { nares }\end{array}$} & \multicolumn{2}{|c|}{ Forearm } & \multicolumn{2}{|c|}{$\begin{array}{c}\text { Dorsum and } \\
\text { palm }\end{array}$} & \multirow[b]{2}{*}{ Total } \\
\hline & & $\mathrm{n}$ & $\%$ & $\mathrm{n}$ & $\%$ & $\mathrm{n}$ & $\%$ & \\
\hline$\overline{<1}$ & CoNS & 1 & 11.1 & 7 & 77.8 & 3 & 33.3 & 11 \\
\hline \multirow[t]{2}{*}{$(\mathrm{n}=9)$} & S. aureus & 4 & 44.4 & 0 & 0.0 & 2 & 22.2 & 6 \\
\hline & MRSA & 4 & 44.4 & 0 & 0.0 & 1 & 11.1 & 5 \\
\hline $1-5$ & CoNS & 2 & 8.3 & 14 & 58.3 & 10 & 41.7 & 26 \\
\hline \multirow[t]{2}{*}{$(n=24)$} & S. aureus & 17 & 70.8 & 3 & 12.5 & 2 & 8.3 & 22 \\
\hline & MRSA & 14 & 58.3 & 2 & 8.3 & 0 & 0.0 & 16 \\
\hline $5-20$ & CoNS & 171 & 39.4 & 71 & 16.4 & 34 & 7.8 & 276 \\
\hline \multirow[t]{2}{*}{$(n=434)$} & S. aureus & 135 & 31.1 & 10 & 2.3 & 18 & 4.2 & 163 \\
\hline & MRSA & 94 & 21.7 & 9 & 2.1 & 13 & 3.0 & 116 \\
\hline $20-40$ & CoNS & 345 & 81.4 & 127 & 30.0 & 93 & 21.9 & 565 \\
\hline \multirow[t]{2}{*}{$(n=424)$} & S. aureus & 52 & 12.3 & 8 & 1.9 & 8 & 1.9 & 68 \\
\hline & MRSA & 42 & 9.9 & 7 & 1.7 & 5 & 1.2 & 54 \\
\hline$>40$ & CoNS & 69 & 63.3 & 43 & 39.5 & 33 & 30.3 & 145 \\
\hline \multirow[t]{2}{*}{$(\mathrm{n}=109)$} & S. aureus & 17 & 15.6 & 3 & 2.8 & 3 & 2.8 & 23 \\
\hline & MRSA & 12 & 11.0 & 2 & 1.8 & 0 & 0.0 & 14 \\
\hline Total $\mathrm{n}$ of samples & CoNS & 588 & 58.8 & 262 & 26.2 & 173 & 17.3 & 1,023 \\
\hline \multirow[t]{2}{*}{$(\mathrm{n}=1,000)$} & S. aureus & 225 & 22.5 & 24 & 2.4 & 33 & 3.3 & 282 \\
\hline & MRSA & 166 & 16.6 & 20 & 2.0 & 19 & 1.9 & 205 \\
\hline
\end{tabular}

CoNS: coagulase negative Staphylococci, S. aureus: Staphylococcus aureus, MRSA: methicillin resistant Staphylococcus aureus. 
TABLE 2 - Distribution of Staphylococci in healthy individuals according to socioeconomic strata.

\begin{tabular}{|c|c|c|c|c|c|c|c|c|}
\hline \multirow[b]{2}{*}{ Socioeconomic status } & \multirow{2}{*}{$\begin{array}{c}\text { Staphylococcal } \\
\text { isolates }\end{array}$} & \multicolumn{2}{|c|}{ Anterior } & \multicolumn{2}{|c|}{ Forearm } & \multicolumn{2}{|c|}{$\begin{array}{c}\text { Dorsum and } \\
\text { palm }\end{array}$} & \multirow[b]{2}{*}{ Total } \\
\hline & & $\mathrm{n}$ & $\%$ & $\mathrm{n}$ & $\%$ & $\mathrm{n}$ & $\%$ & \\
\hline Upper economic class & CoNS & 155 & 47.8 & 85 & 26.2 & 59 & 18.2 & 299 \\
\hline \multirow[t]{2}{*}{$(\mathrm{n}=324)$} & S. aureus & 100 & 30.9 & 10 & 3.1 & 10 & 3.1 & 120 \\
\hline & MRSA & 61 & 18.8 & 6 & 1.9 & 2 & 0.6 & 69 \\
\hline Middle economic class & CoNS & 158 & 67.8 & 67 & 28.8 & 40 & 17.2 & 265 \\
\hline \multirow[t]{2}{*}{$(\mathrm{n}=233)$} & S. aureus & 31 & 13.3 & 5 & 2.2 & 5 & 2.2 & 41 \\
\hline & MRSA & 29 & 12.5 & 5 & 2.2 & 5 & 2.2 & 39 \\
\hline Lower economic class & CoNS & 134 & 74.0 & 40 & 22.1 & 28 & 15.5 & 202 \\
\hline \multirow[t]{2}{*}{$(\mathrm{n}=181)$} & S. aureus & 36 & 19.9 & 9 & 5.0 & 9 & 5.0 & 54 \\
\hline & MRSA & 32 & 17.7 & 3 & 1.7 & 7 & 3.9 & 42 \\
\hline Doctors & CoNS & 14 & 51.9 & 9 & 33.3 & 9 & 33.3 & 32 \\
\hline \multirow[t]{2}{*}{$(n=27)$} & S. aureus & 11 & 40.7 & 1 & 3.7 & 3 & 11.1 & 15 \\
\hline & MRSA & 6 & 22.2 & 1 & 3.7 & 1 & 3.7 & 8 \\
\hline Nurses & CoNS & 100 & 69.4 & 21 & 14.6 & 20 & 13.9 & 141 \\
\hline \multirow[t]{2}{*}{$(\mathrm{n}=144)$} & S. aureus & 26 & 18.1 & 3 & 2.1 & 1 & 0.7 & 30 \\
\hline & MRSA & 23 & 16.0 & 3 & 2.1 & 1 & 0.7 & 27 \\
\hline In-patients & CoNS & 27 & 29.7 & 15 & 16.5 & 17 & 18.7 & 59 \\
\hline \multirow[t]{2}{*}{$(\mathrm{n}=91)$} & S. aureus & 21 & 23.1 & 2 & 2.2 & 5 & 5.5 & 28 \\
\hline & MRSA & 15 & 6.5 & 2 & 2.2 & 3 & 3.3 & 20 \\
\hline Total $\mathrm{n}$ of samples & CoNS & 588 & 58.8 & 262 & 26.2 & 173 & 17.3 & 1,023 \\
\hline \multirow[t]{2}{*}{$(\mathrm{n}=1,000)$} & S. aureus & 225 & 22.5 & 24 & 2.4 & 33 & 3.3 & 282 \\
\hline & MRSA & 166 & 16.6 & 20 & 2.0 & 19 & 1.9 & 205 \\
\hline
\end{tabular}

TABLE 3 - Capsular polysaccharide antigen types in Staphylococcus aureus and MRSA isolates as colonizers from healthy individuals.

\begin{tabular}{|c|c|c|c|c|c|c|c|}
\hline \multirow[b]{3}{*}{ Organisms } & \multirow{3}{*}{$\begin{array}{c}\text { Total } \mathrm{n} \text { of } \\
\text { isolates }\end{array}$} & \multicolumn{6}{|c|}{ Capsular antigen types } \\
\hline & & \multicolumn{2}{|c|}{ T5 } & \multicolumn{2}{|c|}{$\mathrm{T} 8$} & \multicolumn{2}{|c|}{ Non T5/T8 } \\
\hline & & $\mathrm{n}$ & $\%$ & $\mathrm{n}$ & $\%$ & $\mathrm{n}$ & $\%$ \\
\hline Staphylococcus aureus & 282 & 61 & 21.6 & 153 & 54.3 & 68 & 24.1 \\
\hline MRSA & 205 & 43 & 21.0 & 117 & 57.1 & 45 & 21.9 \\
\hline
\end{tabular}

T5: type 5, T8: type 8, MRSA: methicillin resistant Staphylococcus aureus.

\section{DISCUSSION}

Resistance to methicillin and the emergence of MRSA has aroused great concerns all over the world during the last few decades. In this work, a $22.5 \%$ carrier rate for S. aureus and $16.6 \%$ for MRSA was determined among the healthy population. These results are consistent with the other studies from India, where $23 \%$ to $52.2 \% \mathrm{~S}$. aureus colonization has been reported among healthy individuals ${ }^{9-12}$. Though few studies from India observed no MRSA in the community, a prevalence of $16.6 \%$ was determined, which is similar to reports by Saxena et $\mathrm{al}^{9}$, from Delhi (18\%) and Majumdar et al (24\%) from Sikkim ${ }^{9,11}$. However, a previous study by Onanuga et al from Nigeria reported $69 \%$ of MRSA among healthy women in Zaria, Nigeria ${ }^{13}$. In contrast, studies from the USA, Greece and Malaysia have shown less than $1 \%$ colonization of MRSA in healthy individuals ${ }^{14-16}$. Thus MRSA prevalence shows high regional variance. It was quite alarming to note a high incidence of MRSA (54.5\%) colonization among children below 5 years of age.

Vancomycin resistance was observed in $1.4 \%$ of $S$. aureus isolates, which was confirmed by PCR amplification of vanA. Worthy of note was the fact that all the vancomycin resistant strains were resistant to methicillin, except one; ; i.e., one VRSA strain that was sensitive to methicillin was detected, similar to a case reported by Pillai et $\mathrm{al}^{4}$.

Vancomycin has been the standard of care for serious infections and many studies show $100 \%$ positive clinical outcome ${ }^{16,17}$. However, this study determined a $1.8 \%$ incidence of vancomycin resistance in the population also presenting MRSA. These findings support the recent increasing emergence of vancomycin-resistant $S$. aureus worldwide ${ }^{18}$. This is also the first report of VRSA in the area studied. Researchers had predicted that the spread of vancomycin resistance was advancing, but the observation of $1.4 \%$ resistance in this study confirms the establishment of the resistant strain in this region of southern India. Previous findings concerning high vancomycin-resistant MRSA were reported by Prakash et al in Tamil nadu, southern India ${ }^{2}$.

The increased incidence of MRSA and VRSA colonization in the healthy community can be attributed to the indiscriminate use of antibiotics. This is of utmost concern, since $S$. aureus is an opportunistic pathogen that has been implicated as a causative agent in acute food poisoning episodes, toxic shock syndrome, impetigo, scalded skin syndrome, cellulitis, folliculitis and furuncles.

Resistance in MRSA is related to a chromosomal mecA gene that specifies the production of an abnormal penicillin binding protein called PBP2a or PBP21. PBP2a shows decreased affinity for binding beta-lactam antibiotics resulting in resistance not only to methicillin, but to all beta-lactams, including penicillins and cephalosporins ${ }^{19}$. The $m e c A$ gene complex also contains insertion sites for plasmids and transposons that facilitate the acquisition of resistance to other antibiotics. Thus, cross-resistance to non-beta-lactam antibiotics, such as erythromycin, clindamycin, gentamicin, co-trimoxazole and ciprofloxacin, is common ${ }^{20}$. 
The presence of type 8 capsular polysaccharide antigen occurred more frequently than type 5 in both the $S$. aureus and MRSA, in agreement with the findings of Paul et $\mathrm{al}^{8}$.

In conclusion, analysis of the results of this study confirms the need to reassess policies regarding antibiotic use for Staphylococcal infection. Injudicious use of antibiotics will lead to development of multiple drug resistance. Furthermore, regular surveillance of hospital associated infections, including monitoring antibiotic sensitivity pattern of MRSA, and the formulation of a definitive antibiotic policy may be helpful in reducing the incidence of MRSA infection.

\section{CONFLICT OF INTEREST}

The authors declare that there is no conflict of interest.

\section{REFERENCES}

1. Vandenesch F, Naimi T, Enright MC, Lina G, Nimmo GR, Heffernan H, et al. Community-acquired methicillin-resistant Staphylococcus aureus carrying Panton-Valentine leukocidin genes: worldwide emergence. Emerg Infect Dis 2003; 9:978-984

2. Prakash M, Rajasekar K, Karmegam N. Prevalence of Methicillin Resistant Staphylococcus aureus in Clinical Samples Collected from Kanchipuram Town, Tamil Nadu, South India. J Appl Sci Res 2007; 3:1705-1709.

3. Olayinka BO, Olayinka AT, Onaolapo JA, Olurinola PF. Pattern of resistance to vancomycin and other antimicrobial agents in staphylococcal isolates in a university teaching hospital. Afr Clin Exper Microbiol 2005; 6:46-52.

4. Pillai SK, Wennersten C, Venkataraman L, Eliopoulos GM, Moellering RC, Karchmer AW. Development of reduced vancomycin susceptibility in methicillin susceptible Staphylococcus aureus. Clin Inf Dis 2009; 49:1169-1173.

5. Betty AF, Daniel FS, Alice SW. Staphylococcus, Micrococcus and Similar Organisms. In: Betty AF, Daniel FS, Alice SW, editors. Baily and Scott's Diagnostic Microbiology. $11^{\text {th }}$ ed. St. Louis: Mosby Inc; 2002. p. 284.

6. National Committee for Clinical Laboratory Standards. Performance standards for antimicrobial disc susceptibility tests. Document M2- A6. $6^{\text {th }}$ ed. Wayne, Pennsylvania: National Committee for Clinical Laboratory Standards; 1997.p. 19087-19098.

7. Tiwari HK, Sen MR. Emergence of vancomycin resistant Staphylococcus aureus (VRSA) from a tertiary care hospital from northern part of India. BMC Infect Dis 2006; 6:156.

8. Paul SM, Belkum AV, Shivannavar CT, Gaddad SM. Carriage of capsulated strains of Staphylococcus aureus: a population-based study performed in Gulbarga, South India. Epidemiol Infect 2004; 132:831-838.

9. Saxena S, Singh K, Talwar V. Methicillin Resistant Staphylococcus aureus prevalence in community in the East Delhi area. Jpn J Infect Dis 2003; 56:54-56.

10. Santhosh DV, Shobha KL, Bairy I, Rao G, Anand KM, D’Souza J. Nasal screening and survey of pre-clinical medical students from Malaysia for nasal carriage of coagulase positive MRSA and rate of nasal colonization with Staphylococcus species. J Clin Diagn Res 2007; 6:494-499.

11. Majumdar D, Barua A, Paul B. Nasal carriage of methicillin resistant Staphylococci in healthy population of East Sikkim. Ind J Comm Med 2009; 34:364-365.

12. Parasa LS, Kumar LCA, Para S, Atluri VSR, Kumar PR, Shetty CR. Reviews in Infection 2010; 1:117-123.

13. Onanuga A, Oyi AR, Olayinka BO, Onaolapo JA. Prevalence and susceptibility pattern of methicillin resistant Staphylococcus aureus isolates among healthy women in Zaria, Nigeria. Afr J Biotechnol 2005; 4:1321-1324.

14. Kuenhnert MJ, Kruszan-Morin D, Hill HA, McQuillan G, McAllister SK, Fosheim G, et al. Prevalence of Staphylococcus aureus nasal colonization in the United States, 2001-2002. J Infect Dis 2006; 193:172-179.

15. Karapsias S, Piperaki ET, Spiliopoulou I, Katsanis G, Tseleni-Kotsovili A. Methicillin resistant Staphylococcus aureus nasal carriage among healthy employees of the Hellenic air force. Eurosurveillance 2008; 13:1-3.
16. Choi CS, Yin CS, Baker AA, Sakewi Z, Naing NN, Jamal F, et al. Nasal carriage of Staphylococcus aureus among healthy adults. J Microbiol Immunol Infect 2006; 39:458-464.

17. Anupurba S, Sen MRet al. Prevalence of methicillin resistant Staphylococcus aureus in a tertiary referral hospital in eastern Uttar Pradesh. Ind J Med Microbiol 2003; 21:49-51.

18. Rajaduraipandi K, Mani KR, Panneerselvam K, Mani M, Bhaskar M, Manikandan P. Prevalence and antimicrobial susceptibility pattern of methicillin resistant Staphylococcus aureus: a multicentre study. Ind J Med Microbiol. 2006; 24:34-38.

19. Fridkin SK. Vancomycin-intermediate and resistant Staphylococcus aureus: what the infectious disease specialist need to know. Clin Infect Dis 2001; 32: 108-115.

20. Weems JJ. The many faces of Staphylococcus aureus infections. Postgrad Med $2001 ; 110: 24-36$. 